\title{
QUEEN'S
UNIVERSITY
BELFAST
}

\section{On the waterfront: neoliberal urbanism and the politics of public benefit}

Boland, P., Bronte, J., \& Muir, J. (2017). On the waterfront: neoliberal urbanism and the politics of public benefit. Cities, 61,117-127. https://doi.org/10.1016/j.cities.2016.08.012

\section{Published in: \\ Cities}

\section{Document Version:}

Peer reviewed version

Queen's University Belfast - Research Portal:

Link to publication record in Queen's University Belfast Research Portal

\section{Publisher rights}

(c) 2016 Elsevier Ltd. This manuscript version is made available under the CC-BY-NC-ND 4.0 license http://creativecommons.org/licenses/bync-nd/4.0/,which permits distribution and reproduction for non-commercial purposes, provided the author and source are cited.

\section{General rights}

Copyright for the publications made accessible via the Queen's University Belfast Research Portal is retained by the author(s) and / or other copyright owners and it is a condition of accessing these publications that users recognise and abide by the legal requirements associated with these rights.

Take down policy

The Research Portal is Queen's institutional repository that provides access to Queen's research output. Every effort has been made to ensure that content in the Research Portal does not infringe any person's rights, or applicable UK laws. If you discover content in the Research Portal that you believe breaches copyright or violates any law, please contact openaccess@qub.ac.uk. 


\section{ON THE WATERFRONT: NEOLIBERAL URBANISM AND THE POLITICS OF PUBLIC BENEFIT}

\section{Introduction}

In an earlier issue of this journal Murphy and Fox-Rogers (2015, p. 231) argued "a considerable proportion of the debate on the nature of the common good ${ }^{1}$ in planning lacks empirical grounding". More recently Lennon (2016, p. 3) reiterated an established point of disputation in terms of "how the public interest is and ought to be understood". Here we respond to the empirical and conceptual challenges raised by these authors through a study of the politics of public benefit. In an era of neoliberal urbanism the waterfront has become a focal point of planning intervention; however, this raises important political issues concerning the distributional consequences of redeveloping large tracts of derelict land and dilapidated property. The central line of inquiry concerns what benefits, for whom and where emerge on the waterfront under neoliberal urbanism? To answer this, our paper is underpinned by two research questions. One, how is public benefit constructed, understood and measured by local stakeholders? Two, what types of public benefit exist, and who is the waterfront ultimately for? In grounding the empiricism we focus on the neoliberal planning of Belfast's waterfront through a detailed discussion of Laganside (1989-2007) and Titanic Quarter (2001-present). Despite major transformation in Belfast city centre and on the waterfront, plus the ongoing peace process, the imprints of volatile identity politics and severe social deprivation are entrenched in other areas of the city. Given this, Belfast provides a unique and instructive case to critically explore the sociospatialities of public benefit in a neoliberalised, politicised and polarised urban landscape. The structure of the paper is as follows. The next section synthesises the literatures on neoliberalism and public benefit to provide the theoretical framework; then we discuss the research method; sections four, five and six form the analytical body of the paper; the final section draws together the key conclusions and contribution to knowledge.

\section{Theoretical framework}

\subsection{Neoliberal urbanism and public benefit}

Scholars argue we live in an era where the political economy of neoliberal urbanism is hegemonic (Brenner and Theodore, 2002; Jessop, 2002; Mayer and Künkel, 2012; Peck et al., 2009, 2013). Neoliberal tenets include market rationality, deregulation, privatisation, individualism, competitiveness, entrepreneurialism and enterprise (Castree, 2010; Harvey, 2005, 2006; Peck, 2010; Peck and Tickell, 2002, 2006). Since the 1970s these ideas have become embedded in the politics and praxis of governments, institutions and organisations - at all levels of spatial governance - around the globe. For Harvey (2006, p. 145) neoliberalism "swept across the world like a vast tidal wave

\footnotetext{
${ }^{1}$ We prefer public benefit; synonyms include public interest, public good, community interest and community benefit.
} 
of institutional reform and discursive adjustment". Similarly, Massey (2014) argued it impacts significantly on every aspect of our material and cognitive being to the extent that we (as citizens, workers, consumers) consent (consciously and unconsciously) to a neoliberal mode of thinking and behaving. Neoliberalism exhibits a variegated geography around the world (Brenner et al., 2010; Harvey, 2006; Peck et al., 2009). For example, across Europe there is no uniform pattern rather various stages of 'roll-back', 'roll-out' and 'roll-with-it' neoliberalism (Olesen, 2013; following Peck and Tickell, 2002, 2006). Given this, focus is on the 'process of neoliberalisation' capturing its political construction, geographical nuances and place contingencies; it is not a 'realisable condition' but a process of 'actually existing neoliberalism' (Brenner et al., 2012; McGuirk, 2005; Peck et al., 2010).

Since 2008 commentators have debated whether "the free market project is on the ropes" (Peck et al., 2010, p. 94). Notwithstanding rapacious economic turbulence neoliberalism is an 'adaptive regime' (Brenner et al., 2010, 2012), and recent crisis management is 'furthering not dismantling' (Aalbers, 2013a, b) and 'repairing not replacing' (Peck, 2010) neoliberal practice. There is "no serious unsettling of neoliberal ideological hegemony" (Massey, 2014, p. 2034), and so "recent diagnoses envisioning the end of neoliberalism are premature" (Hendrikse and Sidway, 2010, p. 2037). The neoliberal model has not radically changed because 'market fundamentalism' is very hard to displace (Peck et al., 2013; also Meyer and Künkel, 2012; Oosterlynck and Gonzalez, 2013). Neoliberal theory is, however, criticised for its 'exaggerated hegemony' (Featherstone, 2015), 'narrow debates' (Featherstone et al., 2015), 'promiscuity' (Newman, 2014), 'reductivism' (Hall, 2011), 'imprecision and overuse' (Watkins, 2010). We accept neoliberalism is not a universal concept capturing the entirety of socio-spatial change; however, it has explanatory value in relation to a paradigmatic set of core ideas connecting to public benefit.

Under neoliberal urbanism there has been demonstrable change to perceptions of 'the public'. Massey (2014, p. 2036) referred to "the denigration of the notion of "public'" where emphasis is on the right of the individual consumer for 'privatised urban space'. MacLeod (2011) states contemporary urban governance is about protecting a neoliberalised economy and privileging economic interests and consumerist citizenship over community interests. Similarly, Sager (2015, p. 290) queries "another step away from public-collective values to private-individualistic values". With regard to our focus, Lloyd (2006, p. 4) argues neoliberalism has led to the "erosion, dilution and labile nature of public benefit", while Campbell and Marshall (2000, p. 307) identify "the displacement of public interest by customer satisfaction". In terms of location Sager's (2015) study of Norway shows a neoliberalised planning system shifting the civic ethos of public benefit in favour of 'neoliberal business logic'. In the Republic of Ireland Murphy and Fox-Rogers (2015) question whether planners can properly achieve public benefit under neoliberalism. Across the border the planning system in Northern Ireland is becoming an accessory to neoliberal competitiveness 
and powerful pro-market interests, rather than achieving wider public benefit (Boland, 2014).

Public benefit occupies the minds of planning theorists (Alexander, 2002; Campbell and Marshall, 2012; Lennon, 2016; Lloyd, 2006; Mattila, 2016; Moroni, 2004; Murphy and Fox-Rogers, 2015; Tait, 2011), plus urban scholars (Oakley, 2011; Sandercock and Dovey, 2002), human geographers (MacLeod, 2011; Massey, 2014) and political scientists (McGovern, 2008). One dimension to the debate is conceptual in terms of what it means and how we understand it; the other is empirical in relation to how it is measured and who actually benefits. Understanding and measuring public benefit is problematic. Over time the concept has become 'layered, atomised and contested' to the extent that "there is little, if any, consensus on what [it] constitutes" (Lloyd, 2006, p. 6); it is "a concept that has been increasingly contested in the latter half of the $20^{\text {th }}$ Century" (Mattila, 2016, p. 2). Thus, there are questions over whether it is 'grounded in reality' and a 'valid or usable concept' (Alexander, 2002; Campbell and Marshall, 2000, 2012; Murphy and Fox-Rogers, 2015). The issue is a lack of conceptual rigour and empirical clarity leading to "questions as to how public interest is understood, framed, and justified" (Tait, 2011, p. 159). An 'inherent fuzziness' (Murphy and Fox-Rogers, 2015) feeds 'different interpretations' (Sandercock and Dovey, 2002); as such the concept becomes 'difficult to define and assert' (Lloyd, 2006) and can 'mystify rather than clarify' (Campbell and Marshall, 2000, 2012). Despite these shortcomings "it is not so easy to abandon the concept... as sometimes seems to be the case in contemporary political and planning theory" (Moroni, 2004, p. 163). Some sense of 'the public' and 'benefit/interest' is required, however challenging that might be (Campbell and Marshall, 2000, 2012).

Planning is "an activity whose raison d'être is delivering the public interest" (Lennon, 2016, p. 14). In the UK it is a 'core driver' of the planning system and ethical justification for the planning profession (RTPI, 2015). Setting this in a neoliberal context "the rhetoric of "delivery" drives the need for visible signs of change, often with minimal focus on who benefits from the change and whether it is desirable" (Campbell et al., 2014, p. 48). For example, in Northern Ireland the Planning Act (2011), Strategic Planning Policy Statement (SPPS) and Regional Development Strategy 2035 $(\text { RDS })^{2}$ do not define public benefit nor specify who benefits. Given this, we adopt a definition from the Planning Practice Guidance ${ }^{3}$ of the National Planning Policy Framework for England:

\footnotetext{
${ }^{2}$ The Planning Act provides the legislative framework for planning in Northern Ireland; the SPPS is a "statement on important planning matters that should be addressed across Northern Ireland" (DoE, 2015, p. 6); the RDS "provides an overarching strategic planning framework to facilitate and guide the public and private sectors" (DRD, 2012, p. 10).

${ }^{3}$ http://planningguidance.communities.gov.uk/blog/guidance/conserving-and-enhancing-the-historicenvironment/why-is-significance-important-in-decision-taking/\#paragraph 020
} 
"Public benefits may follow from many developments and could be anything that delivers economic, social or environmental progress as described in the National Planning Policy Framework...They should be of a nature or scale to be of benefit to the public at large".

Clearly, reference to 'anything' that brings 'benefit to the public at large' is very generalised. Such a definition allows those involved in spatial planning, urban regeneration and economic development to argue that what they have provided is intrinsically beneficial to local people. It covers a wide spectrum of outcomes and outputs that can represent public benefit: job creation, housing provision, public realm, green space, cultural attractions, land reclamation, building renovation, civic pride, image improvement and tourist numbers. Thereby encompassing significant definitional and measurement breadth. On this, Lloyd (2006, p. 4) opines "the villain of the piece is not the land use planning system...it is the lack of a clear understanding and articulation of the public interest to which it is working". Citing the "public at large' is also problematic because there are different demographics (e.g. age, race, religion, ethnicity, gender, class) that reside, work and socialise in any geographical area. Thus, spatially integrative concepts such as 'the public' and 'the community' are notoriously contestable (Raco, 2000; Staeheli, 2008; Taylor, 2007; Young, 2002), particularly for planners (Mattila, 2016; Tait, 2011). This is especially true in Belfast ${ }^{4}$ with its 'segregated society' (Shirlow and Murtagh, 2006) and distinctive 'territorial politics' (Murtagh, 2002) characterised by 'antagonistic religio-political geographies' (Cunningham and Gregory, 2014), 'ethnic differences' and 'opposing nationalisms' (Boal, 2002). This politics of difference sustained 'the Troubles' 5 that scarred the city for decades. More generally, the diverse and conflictual nature of modern society undermines the existence of a singular 'public at large' and the ontology of public benefit (Alexander, 2002; Moroni, 2004). Different publics have different needs, interpretations and experiences of the economic, social and environmental aspects of public benefit. Moreover, there exist exclusionary factors such as the inability to access jobs, housing and consumption spaces; this is especially true on the waterfront.

\subsection{Public benefit on the waterfront}

A key conceptual and policy tool for neoliberalism is competitiveness (Allmendinger and Haughton, 2013; Bristow, 2011; Lovering, 2007). Bristow (2010) explains neoliberal competitiveness (i.e. creation of competitive firms and by extension competitive

\footnotetext{
${ }^{4}$ The 2011 Census shows Catholics represent $49 \%$ of the population, Protestants $42 \%$. In broad terms Catholic/Nationalists see themselves as Irish, Protestant/Unionists are British. In working class areas housing, education and wider habituation are highly segregated by religion and national identity; this is less evident in middle class areas where there is more social mixing.

${ }^{5}$ Ethno-sectarian violence conducted by Republican (e.g. IRA, INLA) and Loyalist (e.g. UDA, UVF) paramilitaries; the former seeking a united Irish Republic, the latter defending Northern Ireland's British status and loyalty to the Crown. During almost three decades of violence (1969-1998) over 3,500 lives were lost.
} 
economies) is a 'hegemonic discourse' within global policy networks where it remains largely uncontested. This is particularly evident with regard to spatial planning which has experienced a significant degree of neoliberalisation (Allmendinger and Haughton, 2009, 2010). For Gunder (2010, p. 308) "planning is the ideology of contemporary neoliberal space...lubricating...neoliberal formation". Across the European continent neoliberal ideas have become highly seductive for planners (Olesen, 2013, 2014; Sager, 2011, 2015). In the UK the language and logic of neoliberal competitiveness dominates planning discourse, thereby delimiting planners' policy options (Allmendinger and Haughton, 2012, 2015; Campbell et al., 2014; Haughton et al., 2013). However, McGuirk (2005) cautions against the 'triumph of neoliberal rhetoric', while Tait (2011) refers to the enduring tension between (regulatory) planning and (free market) neoliberalism. In her study of Sydney McGuirk (2005) reveals 'hybrid forms of planning' rather than a 'linear transition' from social democratic to neoliberalised planning. Pertinently, while not dismissing the dominance of neoliberal ideas she emphasises the continued role of 'state agency' (also Brenner and Theodore, 2002; Peck et al., 2009).

The focus on neoliberal competitiveness means certain cityspaces assume special significance. Alongside creative hubs and cultural quarters the waterfront is a site for intensified planning attention (Hoyle, 1988, 2000). Like other high profile parts of the city the waterfront is underpinned by a neoliberal network of governance with coalitions of stakeholders seeking to stimulate competitiveness and entrepreneurialism (Bruttomesso, 2001; Harvey, 1989; MacLeod and Jones, 2011; Rubin, 2011). Waterfronts follow a standard formula of fast policy transfer that has gone global (Brownill, 2013). In the 'new politics of lifestyle' (Keil, 2009) this includes expensive apartments, creative, cultural and technological industries and commodified leisure and entertainment spaces (Carmona, 2009; Imrie and Thomas, 1993, 1999; Shaw, 2013; Ward, 2011). In addition, mega structures and signature buildings epitomise the performativity of neoliberal competitiveness on the waterfront (Doucet et al., 2011; Lovering, 2007). Thus, we agree with Oakley (2011, p. 234) that "waterfront renewal is being driven by a neoliberal competitive city paradigm".

In the 'new urban politics' (Cox, 2009, 2011) cities compete for mobile capital, cultural and sporting events, affluent tourists and Florida's (2002a, b, c, 2003, 2005) 'creative classes' whom he argues are the drivers of the 'new creativity age'. Even trenchant critics (e.g. McCann, 2007; Nathan, 2005; Peck, 2005) accept the huge impact his ideas have had on policy makers across the world; it is not stretching the argument too far to posit the 'creatives' are an important target 'public' for city leaders. Here waterfronts play a crucial role in 'sexing up' cities in the 'global beauty contest' that is city branding (Boland, 2013), representing transformative spaces and testifying to a city's resurgence and aspirations of world class status (Chang and Huang, 2011; Kokot, 2008; Sandercock and Dovey, 2002). Regenerated waterfronts are where the 
'creatives' choose to 'live, work and play', satiating their social needs and stimulating their cultural desires. A contentious manifestation of this 'urban privatism' (MacLeod, 2011 ) is the construction of sanitised spaces offering quality of life in a safe and attractive environment for responsibilised citizens (Swyngedouw, 2009, 2011). Consequently waterfronts are reterritorialised with a particular place identity created through 'colonised spaces' privileging up market consumption and high income communities (Bunce and Desfor, 2007; Cowen and Bunce, 2006).

For Oakley (2011, p. 222) neoliberal policies on the waterfront result in "a shift away from collective benefits to a more individual form of public benefit". Manifested in, amongst other things, personal access to salubrious residences and exciting cultural milieu. Another view is that transformed waterfronts deliver wider public benefit through attracting investment, creating jobs and beautifying unsightly land and property. Thus, all citizens ('the public at large') benefit as urban renewal breathes new life into previously dead economic zones; as such, the interests of the private sector lead to public benefit. However, this narrative distracts discussion away from the politics of distribution concerning those other publics who are excluded from the benefits that regeneration brings (Hagerman, 2007; Lennon, 2016; Scharenberg and Bader, 2009). Importantly, the construction of public benefit lies in the hands of powerful actors, i.e. private sector, developers, planners and other state agents, with a discernible neoliberal bent (Holden et al., 2015; Lehrer and Laidley, 2008; Raco, 2000; Sandercock and Dovey, 2002). This links to debates on the 'right to the city' (Harvey, 2003,2008 ) and the 'just city' (Fainstein, 2014). Here, social justice in the neoliberal city must be understood as a collectivist endeavour not individualised consumption; only this can deliver benefit to a sufficient spectrum of the population. For Fainstein (2014, p. 14) "it can change the rhetoric around urban policy from a single-minded focus on competitiveness to a discourse about justice". Similarly, Lennon (2016, p. 2) highlights the need to "ensure that planning operates as an ethically attuned activity focused on 'justice'". An important aspect of this is planners' ability to make non-market-driven choices that opens up possibilities for 'better planning' (Campbell et al., 2014). Connecting to these issues and prefacing our empiricism McGovern (2008, p. 285) states: "the key question is not whether to develop urban waterfronts, but how they should be developed. For what purpose? For whose benefit?"

\section{Research method}

Our methodology 'operationalises' public benefit (after Alexander, 2002) on Belfast's waterfront. The empiricism is driven by two theoretically informed research questions: how is public benefit constructed, understood and measured; what types of public benefit exist, and who is the waterfront ultimately for? Primary data collection involved semi-structured interviews, plus site visits and policy review. We interviewed thirteen representatives from key organisations involved in Belfast's 
waterfront; they were identified using purposeful, reputation and snowball selection ${ }^{6}$ (Table 1). An interview schedule comprised five sections with distinct sets of questions. Section 1 was sub-divided allowing for variations in questioning depending on the participant's sector (e.g. Section 1A: public; Section 1B: private; Section 1C: community/voluntary). Section 1 sought views on waterfront development, roles in the regeneration process, definitions of public benefit and how public benefit was reflected. Section 2 focused on marketing the waterfront, the image it projects and in whose interests. Section 3 questioned the heritage and culture promoted on the waterfront and its representativeness and inclusivity. Section 4 focused on the physical and psychological connection of the waterfront to the city and its people. Section 5 sought respondents' views on the waterfront's future. We recorded interviews on a Dictaphone and uploaded audio files to a secure PC; following transcription a systematic text analysis was conducted through NVivo to generate codes based on respondents' statements. Commonalities and emergent themes were identified, guided by the research questions and theoretical framework. Fieldwork was supplemented by an analysis of socio-economic and demographic data from Northern Ireland Statistics and Research Agency (NISRA). This involved formatting the datasets in Microsoft Excel to prepare for analysis through GIS and ArcMap. The waterfront intersects various wards, super output areas and small areas so there is no specific dataset. Therefore, we mapped the boundaries of Laganside and Titanic Quarter on top of existing NISRA areas enabling us to profile the waterfront in terms of industry and inhabitants, thereby enriching our empiricism.

\section{Table 1 here}

\section{Development of Belfast's waterfront}

The political context for regenerating Belfast's waterfront is the adoption of neoliberal ideas (Boland, 2014; Horgan, 2006; Muir, 2014; Murtagh and Shirlow, 2012). The specificity of Northern Ireland's neoliberal project represented a 'hybrid form' due to its historically contentious and financially dependent role within the UK jurisdiction (Nagle, 2009a). For Newman (2014, p. 3296) studying cities involves "asking how the interplay of multi-scalar actants around a specific project in a specific locality will configure local engagements with neoliberal ideologies". Belfast City Council is an 'active agent' (after Blanco et al., 2013) of neoliberal politics and praxis; more specifically, it is argued "neoliberal competitiveness was the unquestioned policy lever in Belfast" (Boland, 2014, p. 778). Heeding the advice of academic consultants the Council is fixated with achieving 'competitive city' and 'world class' status to attract global capital (Belfast City Council, 2007, 2015). For example, an early Masterplan

\footnotetext{
${ }^{6}$ Named consent included Belfast City Council, CBRE Northern Ireland, Harcourt Developments, Titanic Quarter Ltd, Laganside Development Corporation, Department for Social Development and Titanic Foundation.
} 
argued "in an increasingly open and deregulated global economy there is intense competition for mobile investment" (Ibid., 2004, p. 25).

The waterfront was pivotal for the local economy from the mid-17th century (McCreary, 2011). Belfast became one of the world's busiest ports and wealth accumulation came from shipbuilding, linen weaving, rope making and engineering. The first shipyard opened in 1791 and the 'golden age' of shipbuilding (1880-1914) included launching the Titanic in 1912 (Lynch, 2001). The waterfront suffered in the 1930s Depression and was bombed heavily in 1941. Investment during the 1960s-70s included new facilities for ferries, a new dry dock and the Samson and Goliath cranes. Harland \& Wolff launched its last ship in 2003 and now operates on a reduced scale, repairing ships and oil rigs, and making wind turbines. Port functions and ferry terminal remain making it a working port although at significantly less capacity than in its heyday - the dock workforce shrank from 40,000 to 300. Decline of shipbuilding, and other traditional industries, created acute urban decay in areas close to the city centre. Although Belfast had long turned its back on the river, during the 1980s city leaders viewed the derelict docklands as an opportunity for physical, economic and social renewal. The original vision promised "a high profile European waterfront firmly rooted in the history and character of Belfast, acting as a driver for high quality investment and development in the city" (Turley Associates, 2005, p. 1).

\subsection{Laganside: 'physical and economic transformation'}

Laganside Development Corporation (LDC) was initiated during the political turbulence of 'the Troubles' and economic retrenchment:

"We moved into the Development Corporation in 1989 and at that time it was the worst ever property market recession in Europe, so you can imagine how difficult it was for Belfast to attract investment. We had 'the Troubles' going on and coupled with that there was absolutely no interest in investment" (Interview 4, private sector ${ }^{7}$ ).

Laganside was Northern Ireland's urban development corporation (UDC) with similar responsibilities to those in England and Wales (Imrie and Thomas, 1993, 1999), although it did not have planning powers. LDC's brief was to revitalise 140 hectares of brownfield land on both banks of the River Lagan into an attractive space for businesses and people (Sterrett et al., 2005). A politics of civic normalisation through economic growth was enacted in the Laganside Concept Plan aimed at redeveloping the waterfront and achieving community benefits; the assumption being "private sector development and investment will continue without major public intervention" (Laganside Corporation, 2007, p. 2). LDC adopted the same neoliberal approach as

\footnotetext{
${ }^{7}$ This interviewee currently works for the private sector, but they were an employee of LDC which was a public sector organisation.
} 
other UDCs: delivering infrastructure projects, attracting investment and building offices and apartments for the private market (Fitzsimons, 1995; Nagle, 2009b). A respondent explained the logic:

"Our focus in those days was primarily on the physical and economic regeneration...what we wanted to do was show that we could generate employment and by the 'trickle-down' effect that was a real way of transforming an area...It's not that we ignored community but our main focus in those days was the physical and economic transformation of the waterfront, and we were unashamedly focused on that because without that working everything else was just hot air" (Interview 4, public sector).

\section{Image 1 here}

LDC's remit was extended to cover another 60 hectares including Belfast Gasworks; located near a fiery interface between working class Catholic (lower Ormeau Road) and Protestant (Donegall Pass) communities. Its closure in the mid-1980s left a 10 hectare heavily contaminated site (Image 1). Belfast City Council, in partnership with LDC, injected $£ 150$ million for redevelopment and it is now established as one of Belfast's most vibrant economic hubs, attracting national and international companies such as Lloyds Banking Group, Deloitte Business Management Consultants and Radisson Hotel (Image 2). One study states it created 662,665 sq. m of commercial space (costing $£ 115$ million) and 4,600 jobs (Sterrett et al., 2005). In parts of South and East Belfast laying closest to Laganside there were chronic problems of long term unemployment. In response, Gasworks Employment Matching Service (GEMS) aimed to link local unemployed people with job and training opportunities. Although studies vary in their methodologies the consensus is that GEMS had some positive impact on the local labour market, education and training (Hemphill et al., 2006; McKinstry, 2004; Plöger, 2008; Sterrett et al., 2005).

\section{Image 2 here}

Contrary to an earlier LDC extract, a huge proportion of its $£ 1$ billion budget came from 'state agency' (after McGuirk, 2005). By 1998 it had secured $£ 55$ million from regional government, $£ 29$ million from the European Regional Development Fund, $£ 40$ million for Belfast's Millennium Project and additional sums from Lottery and EU PEACE funds (OECD, 2000). Monies from the public purse financed major projects such as the Custom House Square, Odyssey Arena, Clarendon Dock and Lanyon Place (Image 3). Private investment was sluggish initially, but picked up after the 1994 paramilitary ceasefires and the 1998 Good Friday Agreement ${ }^{8}$ (Neill et al., 2014).

\footnotetext{
${ }^{8}$ Agreement between the British and Irish Governments, and the main political parties in Northern Ireland, paving the path for peace and a political solution to the conflict.
} 
Although detailed ex post statistics proved hard to obtain, by the end of 2007 an investment leverage ratio of 1:5 was predicted (Laganside Corporation, 2007), comparable with other UDCs. Broken down, LDC's achievements included the construction of 229,000 sq. $\mathrm{m}$ of office space, 51,090 sq. $\mathrm{m}$ of leisure and retail space, 15.54 ha of public realm, 4,613 m of walkways and 741 housing units (Laganside Corporation, 2007; Sterrett et al., 2005). So in terms of its original brief Laganside has been a success: the area is a prime business quarter attracting major firms, and a destination for leisure, recreation and entertainment with established festivals, events, hotels, restaurants and bars.

\section{Image 3 here}

\subsection{Titanic Quarter: from White Star to five star}

Further regeneration began from 2001 with the 185 acre, 30 year Titanic Quarter (TQ) project. Identified as a major employment location in the Belfast Metropolitan Area Plan 2015 (DoE, 2014), it is one of Europe's biggest waterfront developments claiming to redefine what it means to 'work, live and play' in Belfast. Following the Good Friday Agreement, TQ was part of a broader civic optimism depicted through the slogan 'A Renaissance for Belfast' (Bairner, 2006). According to Neill (2011, p. 73) the "logic of urban intervention [is] wrapped... inside an urban renaissance agenda and the linked and shared project of building the 'post-conflict' city" (also Shirlow, 2006). Within a divided society it was important for TQ to be a shared space with an inclusive civic identity, fostering a new era for a city recovering from a history of political discord and sectarian violence (see www.titanic-quarter.com). A respondent explained: "Yes, it's like a neutral environment with an 'I'm happy to go there' mentality. As you would in any other city" (Interview 3, public sector).

TQ is the most high profile of 'Belfast's Quarters' ${ }^{9}$ (McManus and Carruthers, 2014). Phase One was completed in 2011 and included 475 apartments, offices, a hotel and new sites for Belfast Metropolitan College and the Public Records Office of Northern Ireland. A Science Park is located on a 10 hectare site, next to the Thompson Graving Dock and Pump House which have become major tourist attractions. Phase One was affected by the post-2008 global economic downturn although much of it eventually materialised. Phase Two was more severely impacted and plans for further offices and residences were not considered seriously until late 2015. The only aspect of Phase Two completed on time was Titanic Belfast (Image 4) which opened on the $100^{\text {th }}$ anniversary of the sinking of the ship in April 2012. The museum is unmistakably TQ's signature project (Ramsey, 2013) and in its first year attracted nearly 800,000 visitors from 128 different countries (Titanic Foundation, 2014).

\footnotetext{
${ }_{9}^{9}$ Cathedral Quarter is the cultural hub in the city centre with a wide range of activities; Gaeltacht Quarter hosts Irish culture, music and language; Queen's Quarter contains the university, Ulster Museum, and a variety of cultural and artistic locations; Linen Quarter captures a major aspect of the city's industrial heritage (once known as 'Linenopolis').
} 


\section{Image 4 here}

Another success is Titanic Studios (Image 5), founded in 2007 in the old Paint Hall where the ships were painted. The film studios were not part of the original Masterplan but emerged from a combination of happenstance and economic pragmatism:

"We stored fertiliser in it for a while and that got some level of return and then the rates people came down and said: 'That's a massive building we are going to charge you serious rates'...So were we going to tumble this building or keep it open for some unspecified use? And then the next thing we knew Tom Hanks' production company were knocking the door...and this is where the serendipity comes in. It was something that nobody had planned or foreseen and suddenly they were over and on the back of that we've had Universal Studios, Game of Thrones and all the rest" (Interview 4, private sector).

\section{Image 5 here}

Like Laganside, despite neoliberal language of marketization, investment and competitiveness the reality is that 'state agency' (after McGuirk, 2005) was crucial for TQ. Ostensibly a private sector led development, the economic downturn hampered the availability of exogenous capital and so considerable sums of public funding was made available. The most striking example is Titanic Belfast; Magee (2012) reveals the total cost of $£ 77$ million received subsidies totalling $£ 60.55$ million $^{10}$. Further examples of pump priming include $£ 2.7$ million from regional government for the Thompson Graving Dock and Pump House; £2.3 million from the EU PEACE III programme towards refurbishing the Nomadic ferry; $£ 5$ million from the Heritage Lottery Fund for the conversion of Harland \& Wolff Headquarters into a boutique hotel; and a £3.4 million loan from InvestNI for the film studios (InvestNI, 2012). Other non-market interventions include two public sector facilities, Belfast Metropolitan College and Public Records Office, and the social economy business T13 Urban Sports Academy. In addition, Titanic Slipway, adjacent to Titanic Belfast, has become a popular site for large scale public entertainment such as concerts, firework displays and sports events, many of which are publicly subsidised. This state dependency had raised concerns for the future; however, from 2014 there was optimism that further regeneration could be achieved with planning permission granted for an extension to the film studios, new offices and an exhibition centre (Mulgrew, 2015). A respondent enunciated the primacy of state intervention:

\footnotetext{
${ }^{10}$ Department for Enterprise, Trade and Investment and Northern Ireland Tourist Board $£ 36.95$ million; Belfast Harbour Commissioners £13.6 million; Belfast City Council $£ 10$ million.
} 
"A lot of what has happened on that site, in fact the vast majority of it, has been as a result of public sector funds. The Paint Hall was funded by the public sector, the college is a public sector project, Titanic Quarter for the most part, well there is private sector money in it, but the vast majority of the money in that building [Titanic Belfast] is public sector money...The Science Park is public sector money. So without that public sector investment there would not have been the development to the extent there has been" (Interview 1, public sector).

The latest phase of TQ focuses on reimaging and rebranding Belfast (Brown et al., 2013; Coyles, 2013; Muir, 2013; Neill, 2011; Neill et al., 2014; Ramsey, 2013). Today, the waterfront is an important space for positioning Belfast in a neoliberalised competitive global order. The 2012-15 Investment Plan states:

"We need to capitalise on our growing reputation as a top cultural and tourism destination, a leading venue for world-class events, a location of choice for foreign direct investment and creative industries, continued political stability, a young population and a skilled workforce" (Belfast City Council, 2012, p. 5).

Developing this point, a respondent emphasised progression from the politics of conflict (Neill, 2014; Shirlow, 2006) to the positivity of rebranding:

"It certainly has allowed us to present Belfast as a modern, growing city which has got significant potential for the future...you've got Game of Thrones one of the biggest blockbusting shows in the USA being filmed there; you've got the Titanic signature building - a world class, really iconic building with real brand value. So having those assets and being able to tell very positive stories about them allows us to present Belfast in a very positive light when historically people have been used to a very different image" (Interview 1, public sector).

On the emergence of 'competitive Belfast' another respondent argued TQ is central to official efforts to promote the city to potential investors:

"It is something new and positive and forward looking and open for business. That is the message that we are putting out more particularly to the world out there that we hope will invest in it" (Interview 2, private sector).

It was surprising to hear a community/voluntary sector respondent articulate the same neoliberal competitiveness mantra; providing further evidence of the political embeddedness of neoliberal thinking in Belfast (Boland, 2014; Muir, 2014; Murtagh and Shirlow, 2012): 


\begin{abstract}
"The strategy at that stage was looking at where we had a competitive advantage over other destinations, and they felt that industrial, maritime heritage gave us that competitive edge over other cities" (Interview 3, community/voluntary sector).
\end{abstract}

\title{
5. Public benefit on Belfast's waterfront
}

We uncovered no specific definition of public benefit amongst our respondents. Instead, reflecting the literature, it was defined in different ways ('anything') and understood in broad terms ('benefit to the public at large'). Based on our interviews we are able to present five categories of public benefit (building on Tait's, 2011, 'two articulations'). Most important is the benefit relating to investment, 'trickle down' economics and tourism. Ramsey (2013, p. 176) argues "TQ is cast as a prime example of how private economic development...can supposedly benefit the whole of the economy and, by extension, the people of Northern Ireland". A respondent explained: "It's absolutely huge with regard to investment... which has brought employment and so on" (Interview 2, public sector). An enhanced image of Belfast was crucial for tourism. The emergence of 'Brand Titanic' (commemorating a sunken ship that cost 1,500 lives) has presaged another successful ('peculiar and perverse') tourist industry ${ }^{11}$ that Belfast, and Northern Ireland, trades upon (Brown et al., 2013; Neill, 2011, 2014). For example, during 201469 cruise ships docked in Belfast (the number doubled since 2011) and in the first three years of its operation over 2 million people visited Titanic Belfast (Deloitte, 2015). A respondent stated: “I think the Titanic is quite unique...It's still a very evocative story which makes people visit. I would see the benefits more in terms of investment and the 'trickle-down' from that" (Interview 7, private sector).

The second category concerns housing. Neither Laganside nor TQ had any existing residents, so the regeneration created communities on the waterfront through new build houses and apartments. Opportunities to live in the waterfront were seen as a public benefit:

"In the early days the developers down at Titanic were looking obviously to highlight the benefits of living along the river and the more prestigious parts of the development that were going to drive how the rest of it happened. So all the waterfront stuff was the most attractive because why wouldn't you want to live somewhere attractive beside water" (Interview 2, community/voluntary sector).

Third is civic pride. Even if local people have not benefitted materially, public benefit emanates from the quality of the revitalised built environment they are able to visit and appreciate. This instils a sense of satisfaction in urban transformation:

${ }^{11}$ Also the sites and signifiers of dark tourism associated with 'the Troubles'. 
"I think we all benefit from having a building [Titanic Belfast] and an experience such as they provide. From family upwards, to those who are coming to visit, and just from a bit of civic pride as well... But there's public benefit in the other buildings as well. You only have to walk through the Metropolitan College to see the standard of facility that is, against what used to be in the city centre here. So there's definitely a public benefit" (Interview 4, private sector).

Fourth, related to civic pride, is the more specific beautification and reuse of the river, such that the waterfront becomes a space that people are attracted to and regard as an asset/benefit for the city:

"When you look back and you look at the old pictures of the waterfront Belfast was an industrial city. The river was an industrial river, and the banks of the river were industrial units that had declined over the years as the world had changed and rivers were maybe not used as much or for industry. With the way industry happened and subsequently changed, there was a huge deterioration in and along the river...But we've now realised that water and the river is an asset. It's a leisure and an amenity asset, it's a nice place to be, people gravitate to it" (Interview 2, public sector).

Finally, there is inclusivity. A respondent informed there was no clear criteria for measuring public benefit; instead, following the literature, reference is made to generalised benefits to the people, and the absence of exclusivity:

“No, I don't think there's any measurement per se, but I can't see anybody losing out. In terms of the regeneration, while it has slowed somewhat, it has created jobs, it has created leisure space, and I don't see any real downside...It is open to everyone...It still has to be commercially viable but I haven't seen anything which has been promoted that actually excludes" (Interview 5, private sector).

\section{Politics of public benefit on Belfast's waterfront}

Here we question the assumptions underpinning these categories of public benefit. The biggest issue for local people is employment. It was estimated 14,700 jobs were created by LDC (Laganside Corporation, 2007), while there are currently over 100 national and international companies employing 4,000 people in TQ (Table, 2; Deloitte, 2015). However, it is unclear how many people from adjacent areas have accessed employment; this information is not publicly available. We know GEMS led to job matching but represented only $7.1 \%$ of total employment at Laganside (Plöger, 2008). We also know the waterfront borders some of the city's most deprived communities. The Markets, Donegall Pass, lower Ormeau Road, Short Strand and inner East Belfast are located within some of the most disadvantaged wards in the city 
such as Ballymacarrett, Botanic and Shaftesbury (www.nisra.gov.uk/). Let us consider Ballymacarrett, situated on the waterfront's southern boundary. Of those aged 16-74 $46 \%$ are economically inactive, $43 \%$ are in paid employment and $61 \%$ have no or low level qualifications. Out of 582 wards in Northern Ireland Ballymacarrett is ranked $6^{\text {th }}$ in terms of Education and Training Disability, and $18^{\text {th }}$ for Multiple Deprivation. Despite propinquity to the waterfront there is no evidence to suggest such publics have benefitted in any substantive manner from the redevelopment (Authors, 2015). For instance, significantly high levels of no or low qualifications exclude large sections of the proximate population from access to jobs given the skills requirements of most employers (i.e. third level qualifications and above). Indeed, the Memorandum of Understanding between TQ and Belfast City Council, aimed at delivering benefits to local communities, was heavily criticised for its lack of action on employment (Muir, 2013). A respondent explained:

"The plan was so overwhelming and all-encompassing and dynamic that actually the clever thing about that is knowing that issues are going to be jobs for people, what types of jobs are going to be available and what are you doing to actually set that in place" (Interview 2, community/voluntary sector).

\section{Table 2 here}

Providing public benefit through social/affordable housing comes about through negotiation or regulation. The problem in Belfast is the absence of an extant community to negotiate with; plus there is no planning gain legislation requiring developers to contribute a proportion of social/affordable housing as a condition of planning permission. To date there is no social/affordable housing in Laganside or TQ despite the construction of 1,216 residential units. TQ Phase Two includes 15\% social/affordable housing as a condition of Belfast City Council's Memorandum of Understanding, largely in response to pressure from the Council amid concerns over the exclusivity of the area (Mulgrew, 2015). By contrast, planning gain legislation in England and Wales has ensured some social/affordable housing provision on Liverpool and Cardiff waterfronts (Authors, 2015). The lack of social/affordable housing is a flaw in claims the waterfront has brought 'benefit to the public at large' as only those in employment are able to afford the mortgages or rents to live there. This may change in the future but presently housing is not a public benefit with regard to the city's poorer publics because they are not financially able to access properties on the waterfront. A respondent informed: “Obviously there have been issues around that site around social housing, and most people would say that to have a vibrant city you need a mix of tenure of housing" (Interview 2, community/voluntary sector).

Given this, we created a residential profile of the waterfront using NISRA datasets (www.nisra.gov.uk/). It shows young professionals dominate the waterfront and, like elsewhere, reflects the fascination and fixation with Florida's 'creative classes'. Age 
structure bunches around 25-34; the majority of households are 1-2 person and inhabitants are single, unmarried or cohabiting with no dependents; two to three room apartments are the main accommodation type, with most privately rented. Residents in full-time work are classified as 'professional' or 'associated professional' working in the information, communication or financial sectors (Table 2). This coincides with rebranding TQ as an exciting place to 'live, work and play' but collides with the politics of alienation amongst working class communities (Catholic and Protestant) towards the waterfront. A respondent explained: "I'm not sure if there are many people in disadvantaged places who got any benefit from it directly" (Interview 2, community/voluntary sector). As noted above neighbouring communities remain seriously disadvantaged, and there is little evidence to suggest these 'publics at large' benefitted to any significant extent. Moreover, the Protestant East Belfast community, with historical links to the docks ${ }^{12}$, feel disconnected towards the new development; while Catholic West Belfast had minimal connection to TQ and failed to see any tangible benefits (Authors, 2015). Moreover, Belfast's territorialised residential geography feeds a politics of take with competing claims from both communities:

"There is a sense that 'look at all the public money that has gone into TQ but when is West Belfast or East Belfast ${ }^{13}$ going to benefit'; because East Belfast doesn't see it as part of them, nor do West, so when are all these other parts of the city going to get their $£ 100$ million of public money. So there is a job to be done by everybody to say 'it's not about TQ it's about Belfast and you live in Belfast so it's about you and here's the benefits you get from it'" (Interview 1, public sector).

Respondents adhered to a view predicated on broad benefits to everyone (e.g. 'I can't see anybody losing out'; 'open to everyone'; 'I haven't seen anything that excludes'; 'we all benefit'). It is true that not every single person will accrue benefit; however, we have issues with the presumption of benefits across society. The current definition of public benefit permits political elites to make bold claims on collective benefits. However, there are reasons to indicate that members of certain publics are excluded from the waterfront. This reality undermines statements such as 'we all benefit' because, even in a very broad collective sense, for many publics it is not true. This connects to Lloyd's (2006, p. 6) comment on "different views on how many members of the public must benefit from an action before it can be declared to be in the public interest". Let us consider claims of wide accessibility to leisure, cultural and entertainment spaces: "I think working class people do visit and take their children to Titanic Belfast" (Interview 5, private sector). However, we note that economic exclusion for certain publics undermines the claim that the waterfront is 'open to

12 The overwhelmingly majority of the shipyard's workforce were Protestant; like other parts of Northern Ireland society at the time Catholics were largely excluded.

${ }^{13}$ The former is predominantly Catholic/Nationalist, the latter Protestant/Unionist. 
everyone'. A fee of $£ 15.50$ per person for the tour of Titanic Belfast is beyond the finances of poor working class people from Catholic and Protestant areas. Also, not all events are free, car parking is expensive and public transport links are less than efficient (poorer families have less access to a car). We accept some working class families have attended free events and maybe Titanic Belfast; however, we suggest they are in a minority as the cost of a family day out in TQ is economically prohibitive for impoverished families. Therefore, for us Belfast's least well-off 'public at large' benefit least from the waterfront.

\section{Conclusions}

In an era of neoliberal urbanism public benefit has been significantly reconfigured in a more individualistic manner, adding to extant concerns over its conceptual clarity, empirical precision and distributional consequences. The most recent contributions to the debate (e.g. Lennon, 2016; Mattila, 2016) approach public benefit in rather abstract conceptual terms; whilst this has value, our paper is both theoretically informed and empirically grounded through a comprehensive study of its actual reality and application in a neoliberalised, politicised and polarised city. In so doing, we offer unique and instructive insights into the politics of public benefit on Belfast's waterfront. The first point is that despite a neoliberal narrative the waterfront has consistently been propped up by 'state agency'. Secondly, understanding and measurement of public benefit is constructed by key political actors with a distinctive neoliberal approach. Their views follow the standard definition of 'anything' that brought 'benefit to the public at large', and from this we identified five categories of public benefit. Thirdly, the distribution of benefit to multiple publics is absent, especially for those least well-off and/or people living in the immediate locality, confirming the presumed impact of neoliberal 'trickle down' benefits has not materialised. Conversely, those who have benefitted most are the young professionals who populate the waterfront. To us, this undermines the argument of 'benefit to the public at large'. Reflecting on our study, we argue public benefit requires ongoing conceptual and practical reconsideration, especially under neoliberal urbanism where it is not effectively 'grounded in reality'. As a classic, now neoliberalised, political construct it is whatever planners, politicians and policy makers say it is, and allows them to assert that any output or outcome inevitably benefits all sections of society. However, is this a problem? For us it is because concepts such as 'the public' conflate diverse groups of people who have very different experiences of waterfront developments. This is coupled with a problematic presumption that society at large benefits but, as we have shown, this is evidently not the case.

Our contribution to knowledge offers more generalizable insights for the academe, other cities and public policy. We urge caution with reference to all-encompassing terms like 'anything' that 'benefit the public at large' because they disguise those who actually do not benefit. It is necessary to problematise assertions that even something intangible - such as civic pride regarding a transformed urban space - is a necessary 
benefit to society. Although it may have some validity, this is an insufficient understanding and measurement of public benefit. Our input to the literature is that in one sense public benefit captures a range of positives for the city and its people; however, when it is unpacked and applied to different demographic groups it becomes deeply problematic. Its current practical utility is undermined as it does not deal efficaciously with important questions concerning the politics of distribution such as who and where actually benefits. We agree that any concept embedded in notions of 'the public' is politically, conceptually and empirically questionable; nevertheless there is a need for some notion of what and how 'the public(s) benefit(s)', especially from a planning perspective, however challenging that may be. Currently, public benefit is a 'valid/usable concept' for those in positions of power; for us, however, it legitimates their decisions leading to outputs and outcomes which we consider unjust. To redress the challenge noted above we suggest there is a need to ensure that public benefit also becomes a 'valid/usable concept' for less powerful groups in society whose objective is to secure more equitable and just access to benefits from major planning interventions. This requires foregrounding the politics of distribution in both policy and practical deliberations on public benefit. Here, future research should provide more detailed excavation of important politico-geographic dimensions of public benefit on the waterfront, and in other spaces of the contemporary city, and offer mechanisms to achieve more democratic and inclusive understandings and measurements of who benefits. Finally, the issues and implications raised by this study offer a contribution to shaping the direction of ongoing international theoretical and empirical debates on the politics of public benefit in an era of neoliberal urbanism.

\section{Funding:}

The research underpinning this paper was funded by the Royal Institute of Chartered Surveyors.

\section{Acknowledgements:}

The authors would like to thank Brendan Murtagh, Huw Thomas, Wesley Flannery, Linda Fox-Rogers, Geraint Ellis, Stephen McKay and the anonymous referees for comments on earlier versions of this paper. 


\section{References}

Aalbers, M. (2013a) 'Debate on Neoliberalism in and after the Neoliberal Crisis'. International Journal of Urban and Regional Research, 37(3): 1053-1057.

Aalbers, M. (2013b) 'Neoliberalism is Dead...Long Live Neoliberalism'. International Journal of Urban and Regional Research, 37(3): 1083-1090.

Alexander, E. (2002) 'The public interest in planning: From legitimating to substantive plan evaluation'. Planning Theory, 1(3): 226-249.

Allmendinger, P., and Haughton, G. (2009) 'Soft spaces, fuzzy boundaries, and metagovernance: the new spatial planning in the Thames Gateway'. Environment and Planning A, 41: 617-633.

Allmendinger, P., and Haughton, G. (2010) 'Spatial planning, devolution, and new planning spaces'. Environment and Planning C: Government and Policy, 28: 803-818.

Allmendinger, P. and Haughton, G. (2012) 'Post-political Spatial Planning in England: A Crisis of Consensus?' Transactions of the Institute of British Geographers, 37(1): 89-103.

Allmendinger, P. and Haughton, G. (2013) 'The Evolution and Trajectories of Neoliberal Spatial Governance: 'neoliberal' episodes in planning'. Planning, Practice and Research, 28(1): 6-26.

Allmendinger, P. and Haughton, G. (2015) 'Post-political regimes in English planning: from Third Way to Big Society'. In Metzger, J., Allmendinger, P. and Oosterlynck, S. (Eds.) Planning Against the Political: Democratic Deficits in European Territorial Governance. London: Routledge, pp. 29-54.

Authors (2015) details to be added after peer review.

Bairner, A. (2006) 'Titanic Town: Sport, Space and the Re-imag(in)ing of Belfast'. City and Society, 18(2): 159-179.

Belfast City Council (2004) Belfast City Masterplan. Belfast: Colin Buchanan \& Partners.

Belfast City Council (2007) Staying Competitive: Belfast City Council's Local Economic Development Plan 2006-2010. Belfast: Belfast City Council.

Belfast City Council (2012) Investment Programme 2012-2015. Belfast: Belfast City Council. 
Blanco, I., Griggs, S. and Sullivan, H. (2014) 'Situating the local in the neoliberalisation and transformation of urban governance'. Urban Studies, 51(15): 3129-3146.

Boal, F. (2002) ‘Belfast: walls within'. Political Geography, 21: 687-694.

Boland, P. (2013) 'Sexing up the city in the international beauty contest: the performative nature of spatial planning and the fictive spectacle of place branding'. Town Planning Review, 84(2): 251-274.

Boland, P. (2014) 'Neoliberal Competitiveness and Spatial Planning: 'The Path to Economic Nirvana' or a 'Dangerous Obsession'?' Environment and Planning A, 46(4): 770-787.

Brenner, N. and Theodore, N. (2002) 'Cities and the Geographies of 'Actually Existing Neoliberalism”. Antipode, 34(3): 349-379.

Brenner, N., Peck, J. and Theodore, N. (2010) 'Variegated neoliberalization: geographies, modalities, pathways'. Global Networks, 10(2): 182-222.

Brenner, N., Peck, J. and Theodore, N. (2012) 'Towards Deep Neoliberalization?' In Künkel, J. and Mayer, M. (Eds.) Neoliberal Urbanism and its Contestations: Crossing Theoretical Boundaries. Basingstoke: Palgrave Macmillan, pp. 27-45.

Bristow, G. (2010) Critical Reflections on Regional Competitiveness. London: Routledge.

Bristow, G. (2011) 'Territorial competitiveness and local and regional economic development: a class tale of 'theory led by policy". In Pike, A., Rodriguez-Pose and Tomaney, J. (Eds.) Handbook of Local and Regional Development. London: Routledge, pp. 344-355.

Brown, S., McDonagh, P. and Shultz, C. (2013) 'A brand so bad it's good: The paradoxical place marketing of Belfast'. Journal of Marketing Management, 29(11-12): 1251-1276.

Brownill, S. (2013) 'Just add water: waterfront regeneration as a global phenomenon'. In Leary, M.E. and McCarthy, J. (Eds.) The Routledge Companion to Urban Regeneration. London: Routledge, pp. 45-55.

Bruttomesso, R. (2001) 'Complexity on the urban waterfront'. In Marshall, R. (Ed.) Waterfronts in post-industrial cities. London: Spon, pp. 39-50.

Bunce, S. and Desfor, G. (2007) 'Introduction to political ecologies of urban waterfront transformations'. Cities, 24(2): 251-258. 
Campbell, H. and Marshall, R. (2000) 'Moral obligations, planning and the public interest: a commentary on current British practice'. Environment and Planning B, 27(2): 297-312.

Campbell, H. and Marshall, R. (2012)[2002] 'Utilitarianism's bad breath? A reevaluation of the public interest justification for planning'. In Feinstein, S. and Campbell, S. (Eds.) Readings in Planning Theory. Oxford: Wiley-Blackwell, pp. 111-131. [Reprinted article from Planning Theory, 2002, 1(2): 163-187]

Campbell, H., Tait, M. and Watkins, C. (2014) 'Is There Space for Better Planning in a Neoliberal World? Implications for Planning Practice and Theory'. Journal of Planning Education and Research, 34(1): 45-59.

Carmona, M. (2009) ‘The Isle of Dogs: Four development waves, five planning models, thirty-five years, and a renaissance... of sorts'. Progress in Planning, 71: 87-151.

Castree, N. (2010) 'Crisis, Continuity and Change: Neoliberalism, the Left and the Future of Capitalism', Antipode 41: 185-213.

Chang, T. and Huang, S. (2011) 'Reclaiming the City: Waterfront Development in Singapore'. Urban Studies, 48(10): 2085-2100.

Cox, K. (2009) 'The politics of local economic development'. In Kitchin, R. and Thrift, N. (Eds.) The International Encyclopaedia of Human Geography. London: Elsevier, pp. 239244.

Cox, K. (2011) 'Commentary. From the new urban politics to the 'new' metropolitan politics'. Urban Studies, 48(12): 2661-2671.

Cowen, D. and Bunce, S. (2006) 'Competitive cities and secure nations: Conflict and Convergence in Urban Waterfront Agendas after 9/11'. International Journal of Urban and Regional Research, 30(2): 427-439.

Coyles, D. (2013) ‘Reflections on Titanic Quarter: the cultural and material legacy of an historic Belfast brand'. The Journal of Architecture, 18(3): 331-363.

Cunningham, N. and Gregory, I. (2014) 'Hard to miss, easy to blame? Peacelines, interfaces and political deaths in Belfast during the Troubles'. Political Geography, 40: 64-78.

Deloitte (2015) A New Story: Titanic Belfast - Evaluation of the first three years. Belfast: Titanic Foundation. 
Department of the Environment (DoE) (2014) Belfast Metropolitan Area Plan Volume 1: Plan Strategy and Framework. Belfast: DoE.

Department of the Environment (DoE) (2105) Strategic Planning Policy Statement for Northern Ireland. Planning for Sustainable Development. Belfast: DoE.

Department for Regional Development (DRD) (2012) Regional Development Strategy. RDS 2035. Building a Better Future. Belfast: DRD.

Doucet, B., van Kempen, R. and van Weesep, J. (2011) ‘Resident perceptions of flagship waterfront regeneration: The case of the Kop van Zuid in Rotterdam'. Tijdschrift voor Economische en Sociale Geografie, 101(2): 125-145.

Fainstein, S. (2014) ‘The just city’. International Journal of Urban Sciences, 18(1): 1-18.

Featherstone, D. (2015) 'Thinking the crisis politically: lineages of resistance to neoliberalism and the politics of the present conjuncture'. Space and Polity, 19(1): 1230 .

Featherstone, D., Strauss, K. and MacKinnon, D. (2015) 'In, against and beyond neoliberalism: The "crisis" and alternative political futures'. Space and Polity, 19(1): 1-11.

Fitzsimons, D. (1995) 'Spearheading a new place vision: the Laganside Corporation'. In Neill, W., Fitzsimons, D.S. \& Murtagh, B. (Eds.) Reimaging the Pariah City: urban development in Belfast and Detroit. Aldershot: Avebury, pp. 77-112.

Florida, R. (2002a) The Rise of the Creative Class: And How It's Transforming Work, Leisure, Community and Everyday Life. New York: Basic Books.

Florida, R. (2002b) 'The Economic Geography of Talent'. Annals of the Association of American Geographers, 92(4): 743-755.

Florida, R. (2002c) ‘Bohemia and Economic Geography'. Journal of Economic Geography, 2(1): 55-71.

Florida, R. (2003) 'Cities and the Creative Class'. City and Community, 2(1): 3-19.

Florida, R. (2005) Cities and the Creative Class. New York: Routledge.

Galland, D. and Hansen, C. (2012) 'The Roles of Planning in Waterfront Redevelopment: From Plan-led and Market-driven Styles to Hybrid Planning?' Planning Practice and Research, 27(2): 203-225. 
Gunder, M. (2010) 'Planning as the ideology of (neoliberal) space'. Planning Theory, 9(4): 298-314.

Hagerman, C. (2007) 'Shaping neighbourhoods and nature: Urban political ecologies of urban waterfront transformations in Portland, Oregon'. Cities, 24(4): 285-297.

Hall, S. (2011) ‘The Neo-Liberal Revolution'. Cultural Studies, 25(6): 705-728.

Harvey, D. (1989) 'From Managerialism to Entrepreneurialism: The Transformation in Urban Governance in Late Capitalism'. Geografiska Annaler: Series B, Human Geography, 71(1): 3-17.

Harvey, D. (2005) A Brief History of Neoliberalism. Oxford: Oxford University Press.

Harvey, D. (2006) 'Neoliberalism as creative destruction'. Geografiska Annaler: Series B, Human Geography, 88(2): 145-158.

Harvey, D. (2008) ‘The Right to the City'. New Left Review, 53: 23-40.

Haughton, G., Allmendinger, P. and Oosterlynck, S. (2013) 'Space of neoliberal experimentation: soft spaces, postpolitics, and neoliberal governmentality'. Environment and Planning A, 45(1): 217-234.

Heeg, S. (2011) 'Flows of Capital and Fixity of Bricks in the Built Environment of Boston'. In Desfor, G., Laidley, J. and Schubert, D. (Eds.) Transforming Urban Waterfronts: Fixity and Flow. London: Routledge, pp. 274-294.

Hemphill, L., McGreal, S., Berry, J. and Watson, S. (2006) 'Leadership, Power and Multisector Urban Regeneration Partnerships'. Urban Studies, 43(1): 59-80.

Hendrikse, R. and Sidway, J. (2010) 'Neoliberalism 3.0'. Environment and Planning A, 42(9): 2037-2042.

Holden, M., Scerri, A. and Esfahani, A. (2015) 'Justifying Redevelopment 'Failures' within Urban 'Success Stories': Dispute, Compromise, and a New Test of Urbanity'. International Journal of Urban and Regional Research, 39(3): 451-470.

Horgan G. (2006) ‘Devolution, direct rule and neo-liberal reconstruction in Northern Ireland'. Critical Social Policy, 26(3): 656-668. 
Hoyle, B. (1988) 'Development dynamics at the port-city interface'. In Hoyle, B., Pinder, D. and Husain, M. (Eds.) Revitalising the Waterfront: International Dimensions of Dockland Development. London: Belhaven Press, pp. 3-19.

Hoyle, B. (2000) 'Global and Local Change on the Port - City Waterfront'. Geographical Review, 90(3): 395-417.

Imrie, R. and Thomas, H. (Eds.) (1993) British Urban Policy: An Evaluation of the Urban Development Corporations. London: Sage.

Imrie, R. and Thomas, H. (Eds.) (1999) British Urban Policy: An Evaluation of the Urban Development Corporations. London: Sage. Second edition.

InvestNI (2012) Robinson and McGuinness - Titanic Studios put local film production facilities on global stage. Accessed on $10^{\text {th }}$ October 2012 via:

www.investni.com/news/robinson-and-mcguinness-titanic-studios-put-local-filmproduction-facilities-on-global-stage.html

Jessop, B. (2002) 'Liberalism, Neoliberalism, and Urban Governance: A StateTheoretical Perspective'. Antipode, 34(3): 452-472.

Keil, R. (2009) 'The urban politics of roll-with-it neoliberalization'. City, 13(2-3): 230245.

Kokot, W. (2008) 'Port Cities as Areas of Transition - Comparative Ethnographic Research'. In Kokot, W., Gandelsman-Trier, M., Wildner, K. and Wonneberger, A. (Eds.) Port Cities as Areas of Transition: Ethnographic Perspectives. Bielefeld: Transcript Verlag, pp. 7-24.

Laganside Corporation (2007) Regeneration Statement. Belfast: Laganside Corporation.

Lehrer, U. and Laidley, J. (2008) 'Old Mega-Projects Newly Packaged? Waterfront Redevelopment in Toronto'. International Journal of Urban and Regional Research, 32(4): 786-803.

Lennon, M. (2016) 'On 'the subject' of planning's public interest'. Planning Theory, Online First: 1-16.

Lloyd, G. (2006) Planning and the public interest in the modern world. The Sir Patrick Geddes Commemorative Lecture 2006, Royal Society of Edinburgh, $9^{\text {th }}$ June. Speech transcript accessed via:

www.rtpi.org.uk/media/579473/transcript - greg_lloyd - 2006.pdf 
Lovering, J. (2007) 'The relationship between urban regeneration and neoliberalism: Two presumptuous theories and a research agenda'. International Planning Studies, 12(4): 343-366.

Lynch, J. (2001) An Unlikely Success Story: The Belfast Shipbuilding Industry 1880-1935. Belfast: Belfast Historical Society and Ulster Historical Foundation.

McCann, E. (2007) 'Inequality and Politics in the Creative City-Region: Questions of Livability and State Strategy'. International Journal of Urban and Regional Research, 31(1): 188-196.

McCreary, A. (2011) Titanic Port: An illustrated history of Belfast Harbour. Belfast: Belfast Harbour Commissioners.

McGovern, S. (2008) 'Evolving Visions of Waterfront Development in Postindustrial Philadelphia: The Formative Role of Elite Ideologies'. Journal of Planning History, 7(4): 295-326.

McGuirk, P. (2005) 'Neoliberalist planning? Re-thinking and re-casting Sydney's metropolitan planning'. Geographical Research, 43(1): 59-70.

McKinstry, D. (2004) 'The Gasworks Employment Matching Service'. Labour Market Bulletin 18, Belfast: Department for Employment and Learning.

McManus, C. and Carruthers, C. (2014) 'Cultural quarters and urban regeneration the case of Cathedral Quarter Belfast'. International Journal of Cultural Policy, 20(1): 7898.

MacLeod, G. (2011) 'Urban politics reconsidered: growth machine to post-democratic city?’ Urban Studies, 48(12): 2629-2660

MacLeod, G. and Jones, M. (2011) 'Renewing urban politics'. Urban Studies, 48(12): 2443-2472.

Magee, K. (2012) Titanic Belfast: Will it rival Disneyland, Tate Modern and the Guggenheim? BBC News 29th March 2012. Accessed 7th September 2015 via: www.bbc.co.uk/news/uk-northern-ireland-17552802.

Massey, D. (2014) 'Symposium: The Kilburn Manifesto: after neoliberalism?' Environment and Planning A, 46(9): 2033-2049. 
Mattila, H. (2016) 'Can collaborative planning go beyond locally focused notions of the "public interest"? The potential of Habermas' concept of "generalizable interest" in pluralist and trans-scalar planning discourses'. Planning Theory, Online First: 1-22.

Mayer, M. and Künkel, J. (2012) 'Introduction: Neoliberal Urbanism and its Contestations - Crossing Theoretical Boundaries'. In Künkel, J. and Mayer, M. (Eds.) Neoliberal Urbanism and its Contestations: Crossing Theoretical Boundaries. Basingstoke: Palgrave Macmillan, pp. 3-26.

Moore, N. (2008) Dublin Docklands Reinvented: The post-industrial regeneration of a European city quarter. Dublin: Four Courts Press.

Morini, S. (2004) 'Towards a reconstruction of the public interest criterion'. Planning Theory, 3(2): 151-171.

Muir, J. (2013) 'Whose Urban Regeneration? Two Belfast case studies'. In Leary, M. and McCarthy, J. (Eds.) Routledge Companion to Urban Regeneration. London: Routledge, pp. 475-485.

Muir, J. (2014) 'Neoliberalising a divided society? The regeneration of Crumlin Road Gaol and Girdwood Park, North Belfast'. Local Economy, 29(1-2): 52-64.

Mulgrew, J. (2015) New social housing project set for Titanic Quarter. Belfast Telegraph, $8^{\text {th }}$ September 2015.

Murtagh, B. (2002) The Politics of Territory: Policy and Segregation in Northern Ireland. Basingstoke: Palgrave.

Murtagh B. and Shirlow P. (2012) 'Devolution and the politics of development in Northern Ireland'. Environment and Planning C, 30(1):30-61.

Murphy, E. and Fox-Rogers, L. (2015) 'Perceptions of the common good in planning'. Cities, 42: 231-241.

Nagle, J. (2009a) 'Potemkin Village: Neo-liberalism and Peace-building in Northern Ireland?' Ethnopolitics, 8(2): 173-190.

Nagle, J. (2009b) 'The right to Belfast City Centre: From ethnocracy to liberal multiculturalism?' Political Geography, 28: 132-141.

Nathan, M. (2005) 'The wrong stuff. Creative class theory, diversity and city performance'. Centre for Cities. Institute for Public Policy and Research. Discussion Paper Number 1. Accessed on $12^{\text {th }}$ July 2005 via: 
www.ippr.org/centreforcities/publicationsandreports/

Neill, W. (2011) 'The Debasing of Myth: The Privatization of Titanic Memory in Designing the 'Post-conflict' City'. Journal of Urban Design, 16(1): 67-86.

Neill, W. (2014) 'Countering the hegemony of the profane: the case for a Titanic Counter-monument in Belfast'. In Neill, W., Murray, M. and Grist, B. (Eds.) Relaunching Titanic: Memory and Marketing in the New Belfast. London: Routledge, pp. 121-130.

Neill, W., Murray, M. and Grist, B. (2014) 'Introduction: Titanic and the New Belfast'. In Neill, W., Murray, M. and Grist, B. (Eds.) Relaunching Titanic: Memory and Marketing in the New Belfast. London: Routledge, pp. 3-13.

Newman, J. (2014) 'Landscapes of Antagonism: Local Governance, Neoliberalism and Austerity'. Urban Studies, 51(15): 3290-3305.

Oakley, S. (2011) 'Re-imagining City Waterfronts: A Comparative Analysis of Governing Renewal in Adelaide, Darwin and Melbourne'. Urban Policy and Research, 29(3): 221-238.

Olesen, K. (2013) 'Soft spaces as vehicles for neoliberal transformations of strategic spatial planning'. Environment and Planning C, 30(5): 288-303.

Olesen, K. (2014) 'The neoliberalisation of strategic spatial planning'. Planning Theory, 13(3): 288-303.

Oosterlynck, S. and Gonzalez, S. (2013) “Don't Waste a Crisis': Opening up the City Yet Again for Neoliberal Experimentation'. International Journal of Urban and Regional Research, 37(3): 1075-1082.

OECD (2000) Urban Renaissance: Belfast's Lessons for Policy and Partnership. Paris: Organisation for Economic Co-operation and Development.

Peck, J. (2005) 'Struggling with the Creative Class'. International Journal of Urban and Regional Research, 29(4): 740-770.

Peck, J. (2010) Constructions of Neoliberal Reason. Oxford: Oxford University Press.

Peck, J. and Tickell, A. (2002) 'Neoliberalizing Space'. Antipode, 34(3): 380-404. 
Peck, J. and Tickell, A. (2006) 'Conceptualizing Neoliberalism, Thinking Thatcherism'. In Leitner, H., Peck, J. and Sheppard, E. (Eds.) Contesting Neoliberalism: Urban Frontiers. New York: The Guilford Press, pp. 26-50.

Peck, J., Theodore, N. and Brenner, N. (2009) `Neoliberal Urbanism: Models, Moments, Mutations'. SAIS Review, 29(1): 49-66.

Peck, J., Theodore, N. and Brenner, N. (2010) 'Postneoliberalism and its Malcontents'. Antipode, 41: 94-116.

Peck, J., Theodore, N. and Brenner, N. (2013) 'Neoliberal Urbanism Redux?' International Journal of Urban and Regional Research, 37(3): 1091-99.

Plöger, J. (2008) Case Study 5: Belfast's Gasworks Employment Matching Service. CASE Report 54, London: Centre for the Analysis of Social Exclusion.

Raco, M. (2000) 'Assessing community participation in local economic development lessons for the new urban policy'. Political Geography, 19(5): 573-599.

Ramsey, P. (2013) “A Pleasingly Blank Canvas': Urban Regeneration in Northern Ireland and the Case of Titanic Quarter'. Space and Polity, 17(2): 164-179.

Royal Town Planning Institute (RTPI) (2015) Corporate Strategy 2015-2020. London: RTPI.

Rubin, J. (2011) 'San Francisco's Waterfront in the Age of Neoliberal Urbanism'. In Desfor, G., Laidley, J. and Schubert, D. (eds.) Transforming Urban Waterfronts: Fixity and Flow. London: Routledge, pp. 143-165.

Sager, T. (2011) 'Neo-liberal urban planning policies: A literature survey 1990-2010'. Progress in Planning, 76(4): 147-199.

Sager, T. (2015) 'Ideological traces in plans for compact cities: Is neo-liberalism hegemonic? 'Planning Theory, 4(3): 268-295.

Sandercock, L. and Dovey, K. (2002) 'Pleasure, Politics, and the 'Public Interest': Melbourne's Riverscape Revitalization'. Journal of the American Planning Association, 68(2): 151-164.

Scharenberg, A. and Bader, I. (2009) 'Berlin's waterfront site struggle'. City, 13(2-3): 326-335. 
Shaw, K. (2013) 'Docklands Dreamings: Illusions of Sustainability in the Melbourne Docks Redevelopment'. Urban Studies, 50(11): 2158-2177.

Shirlow, P. (2006) 'Belfast: the 'post-conflict' city'. Space and Polity, 10(2): 99-107.

Shirlow, P. and Murtagh, B. (2006) Belfast: Segregation, Violence and the City. London: Pluto.

Staeheli, L. (2008) 'Citizenship and the problem with community'. Political Geography, 27(1): 5-21.

Sterrett, K., Murtagh, B. and Millar, G. (2005) ‘The social turn and urban development corporations'. Planning Practice and Research, 20(4): 373-390.

Swyngedouw, E. (2009) 'The antimonies of the postpolitical city: in search of a democratic politics of environmental production'. International Journal of Urban and Regional Research, 33(3): 601-620.

Swyngedouw, E. (2011) 'Interrogating post-democratization: Reclaiming egalitarian political spaces'. Political Geography, 30(7): 370-380.

Tait, M. (2011) 'Trust and the public interest in the micropolitics of planning practice.' Journal of Planning Education and Research, 31(2): 157-171.

Taylor, M. (2007) 'Community Participation in the Real World: Opportunities and Pitfalls in New Governance Spaces'. Urban Studies, 44(2): 297-317.

Titanic Quarter Ltd (2015) TQ Office Brochure. Belfast: Titanic Quarter.

Turley Associates (2005) Titanic Quarter Development Framework. Belfast: Titanic Quarter Ltd.

Ward, S. (2011) 'Port Cities and the Global Exchange of Planning Ideas'. In Hein, C. (Ed.) Port Cities: Dynamic Landscapes and Global Networks. London: Routledge, pp. 7085.

Watkins, S. (2010) 'Shifting Sands'. New Left Review, 61: 5-27.

Young, I. (2002) 'The Ideal of Community and the Politics of Difference'. In Bridge, G. and Watson, S. (Eds.) The Blackwell City Reader. London: Blackwell, pp. 430-439. 